\title{
Psychoanalytic psychotherapy and the pregnant therapist: A literature review
}

\author{
Fernanda Munhoz Driemeier Schmidt ${ }^{1 凶}$, Guilherme Pacheco Fiorini ${ }^{1}$, \\ $\&$ Vera Regina Röhnelt Ramires ${ }^{1}$
}

\begin{abstract}
Researchers and clinicians seem to agree that the psychotherapist's pregnancy is an unique moment of psychotherapy psychoanalytic process. In Brazil, $89 \%$ of psychologists belong to the female gender, being that the practice of psychotherapy, in its great majority, is performed by women. In spite of the relevance of the subject and of its impact on psychotherapies, there are few current studies, most of them dealing with adult patients. The objective of this study was to perform a systematic review of the literature about pregnancy of the psychotherapist in psychoanalytic psychotherapy. All the articles found in the search of indexed scientific publications, which can be accessed on-line, with an approach about the pregnant psychotherapist in psychoanalytic psychotherapy, were included and discussed in this revision. Besides this, the methods, the results and the repercussions of the treatment, were analyzed. It is revealed that there is a lack of studies in this area, because most of the found articles were dated twelve years ago or more. The studies are of a qualitative exploratory methodology, with small samples, from retrospective data collection from the period when the therapists were pregnant. Pregnancy is discussed as a strong catalyzer for the transference and/or for countertransferential reactions. No items of research were found on the subject from the patient or his family's perspective, as well as studies about the psychoanalytic psychotherapy process. It is concluded that other studies on this issue are necessary for the better understanding of this psychotherapeutic moment.
\end{abstract}

Keywords: therapist's pregnancy, psychoanalytic psychotherapy; child psychotherapy

\section{Introduction}

Psychoanalytic psychotherapy refers to a process that aims to provide the individual with tools for an increase of knowledge regarding its functioning, which results in the use of more mature defenses in order to deal with psychic conflicts, in the improvement of the standard of object relations (Eizirik \& Hauck, 2007) and in significant symptomatic changes (Kernberg, 2006; Williams, 2007). In this perspective, the significant traits of the nature of the patient's relationships (including the relationship with the therapist) are ex-

\footnotetext{
${ }^{1}$ Universidade do Vale do Rio dos Sinos (UNISINOS)

$\triangle$ Corresponding author: Fernanda Munhoz Driemeier Schmidt - Rua Casemiro de Abreu 370, apto 402, Porto Alegre, RS, Brazil, 90420-000;

email to: fernandadriemeier@hotmail.com
}

perienced, explored, understood and elaborated during the course of a treatment.

Most of the research in psychotherapy is directed towards the investigation of the results and of the technical interventions used by the psychotherapists, although, less frequently, there also appear some items of research related to the complex participation that the therapist has in the process (Beutler, Malik, Ali Mohamed, Harwood, Talebi, Noble, \& Wong, 2004; Ceitlin, Wiethaeuper, \& Goldfeld, 2003). In spite of there being studies that indicate that the role of the psychotherapist is very important and the aspects related to the therapist are associated and are often predictive of the results of psychotherapies (Beutler et al., 2004; Ceitlin et al., 2003).

In Brazil, the practice of psychotherapy is, mostly, performed by women. Out of the list of psychologists registered in the Federal Council of Psychology (Con- 
selho Federal de Psicologia; CFP), $89 \%$ belong to the female gender and, out of these, $34 \%$ work with clinical psychology (Lhullier \& Roslindo, 2013). In the population of child and adolescent analysts, linked to the International Psychoanalytical Association (IPA) and to the Brazilian Psychoanalysis Association $(\mathrm{ABP}), 78 \%$ of their members are women (Caron, Bornhold, Modzrak, Heck, Wolf, \& Fortes, 2000). Therefore, to study factors associated with the female gender is very important. The pregnancy of the psychotherapist is perhaps the most important one, since it seems to be quite experienced in clinical practice but very little studied through research (Wolfe, 2013). The importance of this issue is heightened, when we consider that in psychoanalytic theory, the therapeutic relationship between patient and therapist is a central point, and that the subjectivity of the therapist is present and influences the way the therapy unfolds (Filho, 2010; Wolfe, 2013; Zimerman, 2007).

Pregnancy is a moment of physical and emotional changes, that can be a positive experience but which can also cause anxiety and stress. It is a moment of transition in the vital cycle of a woman, in which she renegotiates her personal and professional identity, adjusts relationships and develops a new relation with her baby during the preparation for the experience of maternity/motherhood (Etchegoyen, 1993; Fallon \& Brabender, 2003).

In the literature, specific issues are described, with which the pregnant psychotherapist needs to deal with: exposure of anonymity, issues about her sexuality, anxiety about her patient's reactions and the attempt to integrate the psychotherapist with the role of the mother (Fenster Phillips, \& Rapo-port, 1986). There is an exposure of the reality of the therapist's life, in a prolonged, clear and continuous way. There are changes in her appearance, a greater physical and emotional vulnerability and alteration of roles. The increase in vulnerability implies a higher demand of resources for the psychic work and the desires and worries about the baby can go against the therapeutic process (Etchegoyen, 1993; Luz, Keidann \& Dal Zot, 2006).

The perception of the pregnancy occurs in a particular and specific way with each patient and can have many unfoldings, considering the pairs, patient and psychotherapist, with transference and crossed countertransference that may occur (Araújo, 2005). The psychotherapist's pregnancy has significant implications, potentially disturbing and/or facilitating, in the therapeutic process. It is a moment that offers a rich opportunity for the emotional growth of the patient and of the psychotherapist, both individually as well as the pair (Fuller, 1987). The resistance of the patient, the stage of the treatment, the existing level of trust, the countertransference and the psychotherapist's technique, determine how the pregnancy will have an influence on the therapeutic course (Luz et al., 2006).

The clinical focus should be on how the analytic situation is modified under these circumstances and how it can be maintained. The changes vary from the most objective and formal (such as the need of changing schedules or managing them in order for the therapist to undergo exams or consultations) up to the slower, gradual and subtle ones (such as the internal shifts in the therapist's mind) (Luz et al., 2006).

Bassen (1998) when interviewing therapists that were pregnant, perceived that the therapists can find difficulties to facilitate their patient's expression of anger, tending not to interpret sadistic and hostile associations. On the other hand, some tell about positive and lasting changes in their work, parting from their personal experience, feeling more active, self-confident and able to work with aspects of pregnancy, maternity and losses.

Wolfe (2013) also analyzed the impact of the therapist's pregnancy on the patient. She identified that the therapist's pregnancy seems to offer a period where therapist and patient can go beyond the limits, transcending the therapist patient relation, being this a moment in which both are going through complex changes that can simultaneously be thrilling and turbulent.

On the other hand Hacham-Lynch (2014) sought to explore the effects of the psychotherapist being pregnant, from the psychotherapists point of view. The results mainly revealed three points: a feeling of discomfort due to the exposure of the personal life, a need to be a sufficiently good mother for her patients and for her baby at the same time, and pregnancy as a catalyzer of transferential and countertransferential reactions. The analysts who participated in the study reported a greater difficulty in working with the negative transference and loss issues, feeling sometimes guilty about their patients and other times worried about the wellbeing of the baby, mainly in the first pregnancy.

The results of these studies follow the line that the psychotherapist's pregnancy influences and defines the therapeutic relation. However, there is no consensus regarding if the repercussion is positive or negative for the treatment (Wolfe, 2013). Faced with this data, it is important also to know how these factors are expressed in adult and child psychothe-rapy. Being thus, this study had as its objective to perform a systematic review of the literature about the psychotherapist's pregnancy, in psychoanalytical psychotherapy, besides identifying the similitudes and differences on the impact of pregnancy when treating children and adults, as well as if therapist's pregnancy implies some risk for the continuity of the process. The hypothesis raised were: 1) the psychotherapist's pregnancy has an impact on the psychotherapeutic process, according to the studies reviewed; and 2) in child psycho-therapy, that rebound is greater, due to the age group issue and the probable proximity of the experience in the family of origin. 


\section{Method}

The search and analysis of bibliographical material were conducted in four stages. In the first stage, the electronic data-bases BVS-Psi, SCOPUS, Science Direct, EBSCO, Index Psi, PePSIC, Web of Science, LILACS, SciELO, PsycINFO and PubMed were consulted. The describers used were "therapist pregnancy" and "pregnant therapist", without any other combination of words. In the second stage, the inclusion criteria were established: a) original studies, b) approach, as main subject, the psychotherapist's pregnancy in psychotherapy, c) make the whole text available and d) that it be in English, Portuguese or Spanish. No limitations were established regarding the year of publication. Later, during the third stage, a thorough analysis was carried out, in full, of the pre-selected articles, by two researchers, independently, to define the final number of studies to be reviewed, that met the inclusion criteria. Having defined the studies, those results were organized according to the following information: year of publication, authors, objecti-ves, design and results. In the fourth stage, the articles were analyzed regarding their methodological characteristics and results.

\section{Results and Discussion}

Fifty-one studies were found ( 30 were considered, after removing duplicates). Out of these, 8 were excluded for not presenting availability of the complete text $(n=6)$ and 2 for constituting editorial comments $(n=2)$. The 22 remaining articles were read in their entirety (Figure 1).

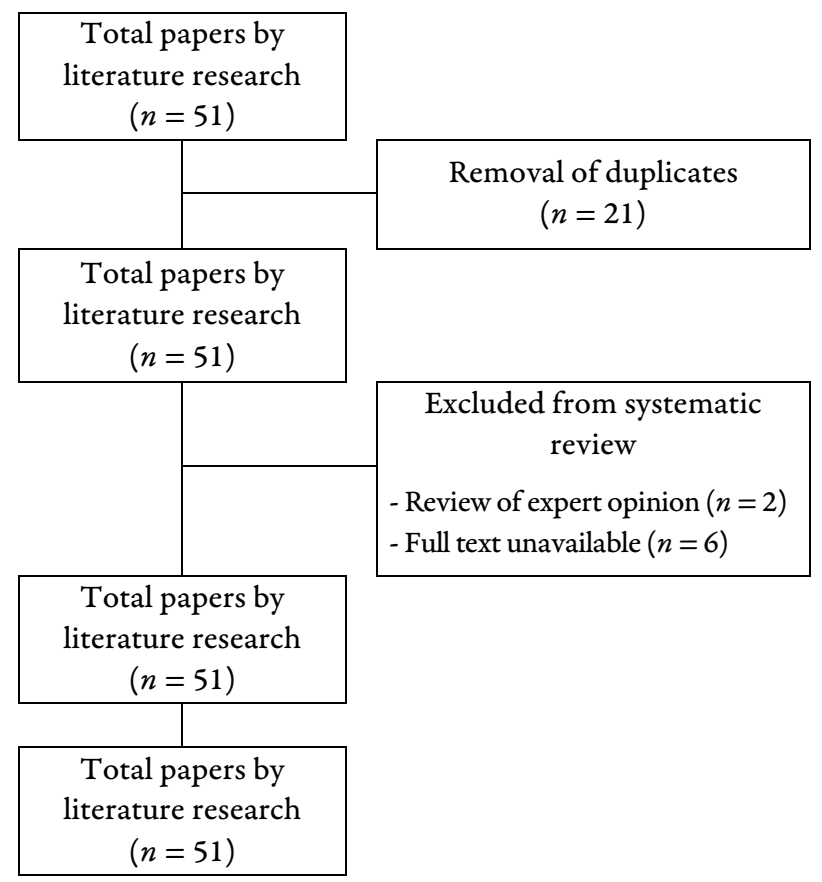

Figure 1. Flow diagram of the reviewed articles

The studies with adult patients show results in which the psychotherapist's pregnancy makes itself present in the setting in a marked way (Bienen, 1990; Chiaramonte, 1986; Cole, 1980; Diamond, 1992; Domash, 1984; Korenis \& Billick, 2014; Korol, 1995; Napoli, 1999; Rosenthal, 1990; Stockman \& Greenemrich, 1994; Tinsley \& Mellman, 2003; Tonon, Romani \& Grossi, 2012, Underwood \& Underwood, 1976). They emphasize the impact of pregnancy on the patient and how the therapist realized this (Bienen, 1990; Dyson \& King, 2008; Korenis \& Billick, 2014; Korol, 1995; Stuart, 1997; Tinsley \& Mellman, 2003, Tonon et al., 2012).

In many treatments, it is the first time that information appears about the real psychotherapist (Al-Mateen, 1991; Korenis \& Billick, 2014; Korol, 1995; Stockman \& Green-Emrich, 1994; Tonon et al., 2012). The studies with pregnant therapists, and with adult patients, discuss the professional limit between psychotherapist and patient, how both deal with this change and the reactions of the patients faced with the gestation (Al-Mateen, 1991; Bienen, 1990; Chiaramonte, 1986; Cole, 1980; Diamond, 1992; Dyson \& King, 2008; Genende, 1988; Korenis \& Billick, 2014; Korol, 1995; Stockman \& Green-Emrich, 1994; Stuart, 1997; Rosenthal, 1990; Tinsley, 2000; Tinsley \& Mellman, 2003). Some studies tell that the patients are more prone to ask the therapist personal questions, due to the pregnancy, and that the therapists tend to answer in a more honest and direct way (Al-Mateen, 1991; Genende, 1988; Korenis \& Billick, 2014; Stockman \& Green-Emrich, 1994; Tonon et al., 2012). The patients tend to bring the therapists more presents during the gestation and the therapists tend to accept the presents (Stockman \& Green-Emrich, 1994). Other studies discuss the consequences of the gradual physical changes in the psychotherapist (Al-Mateen, 1991; Korenis \& Billick, 2014; Korol, 1995; Stuart, 1997; Tinsley, 2000).

The vast majority of studies state that pregnancy can be an opportunity for the patient to work his/her most primitive fantasies, being one more way to access the unconscious and its desires (Al-Mateen, 1991; Bienen, 1990; Diamond, 1992; Domash, 1984; < Rosenthal, 1990; Tonon et al, 2012). This material will appear in therapeutic relation and transferential and countertransferential phenomena within the pregnancy's context (Bienen, 1990; Diamond, 1992; Domash, 1984; Napoli, 1999; Rosenthal, 1990; Tinsley \& Mellman, 2003, Tonon et al., 2012; Underwood \& Underwood, 1976).

Almost all the articles consulted are rich in clinical examples that present, in a clear way, the expressions and transferential manifestations in several cases attended to by the authoresses. Those studies describe that the patient's reactions, when faced with the therapist's pregnancy, can be complex and involve ambivalent thoughts and feelings (Bienen, 1990; Cole, 1980; Diamond, 1992; Korenis \& Billick, 2014; Korol, 1995; Tinsley \& Mellman, 2003; 
Underwood \& Underwood, 1976). Feelings of jealousy, resentment, competitivity, as well as the discussions about having children, sexuality, happiness for the therapist and the desire of undergoing that experience (Diamond, 1992; Korol, 1995). Issues such as rejection, anger, rivalry between siblings and identification with the psychotherapist or with the baby (Genende, 1988; Tinsley \& Mellman,
2003). The reaction to the pregnancy varies depending on the diagnosis, character structure and the patient's level of functioning, as well as their life circumstances and experiences (Cole, 1990; Genende, 1988).

Parting from their clinical experience, Genende (1988) and Underwood and Underwood (1976) agree that during the treatment, issues emerge that

Table 1a. Articles About Pregnant Therapist with Adult Patients

\begin{tabular}{|c|c|c|c|c|}
\hline Author & Year & Objective & Study Design & Results \\
\hline $\begin{array}{l}\text { Underwood, M. , \& } \\
\text { Underwood, E.D. }\end{array}$ & 1976 & $\begin{array}{l}\text { Illustrate and report the re- } \\
\text { actions of the patients and } \\
\text { clinical observations during } \\
\text { the therapist's } \\
\text { pregnancy }\end{array}$ & $\begin{array}{l}\text { Experience } \\
\text { report }\end{array}$ & $\begin{array}{l}\text { The reactions of the patients vary according to the } \\
\text { gestational period and with the operating } \\
\text { dynamics and personality structure of each patient. }\end{array}$ \\
\hline Cole, D. & 1980 & $\begin{array}{l}\text { Illustrate and discuss the } \\
\text { possible effects of the } \\
\text { therapist's pregnancy in the } \\
\text { therapeutic process with } \\
\text { three female patients. }\end{array}$ & $\begin{array}{l}\text { Experience } \\
\text { report }\end{array}$ & $\begin{array}{l}\text { The reaction of the patient is compatíble with } \\
\text { his/her operating dynamics. Those reactions and } \\
\text { feelings interfere in the treatment and the } \\
\text { transference becomes more intense. }\end{array}$ \\
\hline Domash, L. & 1984 & $\begin{array}{l}\text { Illustrate the solving of } \\
\text { pre-oedipal conflicts in } \\
\text { patients being attended to } \\
\text { while the therapist becomes } \\
\text { pregnant. }\end{array}$ & $\begin{array}{l}\text { Experience } \\
\text { report }\end{array}$ & $\begin{array}{l}\text { The therapist's pregnancy facilitates that the pre- } \\
\text { oedipal contents to appear in the treatment and can } \\
\text { be worked on through the transference. }\end{array}$ \\
\hline Chiaramonte, J.A & 1986 & $\begin{array}{l}\text { Discuss about the pregnant } \\
\text { therapist and the maternity } \\
\text { leave during psychotherapy } \\
\text { treatments }\end{array}$ & $\begin{array}{l}\text { Experience } \\
\text { report }\end{array}$ & $\begin{array}{l}\text { Discusses the end of treatment and / or break and a } \\
\text { temporary transfer. In some situations there is the } \\
\text { need of a substitute therapist. }\end{array}$ \\
\hline Genende, J. & 1988 & $\begin{array}{l}\text { Discuss the impact of the } \\
\text { therapist's pregnancy on the } \\
\text { therapeutic process. }\end{array}$ & $\begin{array}{l}\text { Experience } \\
\text { report }\end{array}$ & $\begin{array}{l}\text { Pregnancy has a positive impact on the therapeutic } \\
\text { process, intensifying the mother, child and sexual } \\
\text { transference, of competition and identification } \\
\text { with the creative process. }\end{array}$ \\
\hline Bienen, M. & 1990 & $\begin{array}{l}\text { Illustrate and discuss the } \\
\text { reactions against } \\
\text { transferences in the } \\
\text { pregnant therapist. }\end{array}$ & $\begin{array}{l}\text { Experience } \\
\text { report }\end{array}$ & $\begin{array}{l}\text { It is more difficult for the therapist, during } \\
\text { pregnancy, to deal with her countertransferential } \\
\text { feelings. Those feelings, if well understood and ana- } \\
\text { lyzed, can help in the understanding and work of } \\
\text { the transference, if not, it might lead to a } \\
\text { distancing of the pair or to the ending of the } \\
\text { treatment. }\end{array}$ \\
\hline Rosenthal, E.S. & 1990 & $\begin{array}{l}\text { Discuss the repercussions of } \\
\text { the pregnancy on the } \\
\text { patient, on the therapist and } \\
\text { on the process of the } \\
\text { treatment. }\end{array}$ & $\begin{array}{l}\text { Experience } \\
\text { Report }\end{array}$ & $\begin{array}{l}\text { Pregnancy influences the therapeutic process and } \\
\text { the therapist-patient relation. Increases the } \\
\text { consciousness of the patient's conflicts, making the } \\
\text { transference more intense. Pregnancy is } \\
\text { characterized as a phase of modifications of the } \\
\text { professional identity of the therapist. }\end{array}$ \\
\hline Al-mateen, C.S. & 1991 & $\begin{array}{l}\text { Discuss the repercussions in } \\
\text { the psychotherapy process } \\
\text { when therapist and patients } \\
\text { become pregnant simulta- } \\
\text { neously. }\end{array}$ & $\begin{array}{l}\text { Experience } \\
\text { report }\end{array}$ & $\begin{array}{l}\text { Possibility of working on femininity, dependence, } \\
\text { abandonment and issues related to sexuality. }\end{array}$ \\
\hline Diamond, D. & 1992 & $\begin{array}{l}\text { Identify the differences in } \\
\text { the transference and the } \\
\text { countertransference with } \\
\text { patients, both men and } \\
\text { women, during the } \\
\text { therapist's pregnancy }\end{array}$ & $\begin{array}{l}\text { Experience } \\
\text { report }\end{array}$ & $\begin{array}{l}\text { For men and women pregnancy evokes procreative } \\
\text { efforts and a maternal identification. For women } \\
\text { pregnancy recapitulated her childish desires and of } \\
\text { identification with the feminine, with men it } \\
\text { triggered a strong regression. }\end{array}$ \\
\hline
\end{tabular}


Table 1b. Articles About Pregnant Therapist with Adult Patients

\begin{tabular}{|c|c|c|c|c|}
\hline Author & Year & Objective & Study Design & Results \\
\hline $\begin{array}{l}\text { Stockman, A.F., \& } \\
\text { Green-Emirich, A. }\end{array}$ & 1994 & $\begin{array}{l}\text { Review of the literature } \\
\text { about the therapist's } \\
\text { pregnancy and the impact } \\
\text { on the psychotherapeutic } \\
\text { process }\end{array}$ & $\begin{array}{l}\text { Literature } \\
\text { review }\end{array}$ & $\begin{array}{l}\text { All studies are case reports. Suggest five elements as } \\
\text { important: the therapeutic contract, the therapist's } \\
\text { interventions, the therapeutic relationship, the } \\
\text { patient's reactions and the therapist's perceptions }\end{array}$ \\
\hline Korol, R. & 1995 & $\begin{array}{l}\text { Discuss the impact of the } \\
\text { therapist's pregnancy in the } \\
\text { treatment process }\end{array}$ & $\begin{array}{l}\text { Experience } \\
\text { report }\end{array}$ & $\begin{array}{l}\text { Pregnancy, if well worked, can improve the overall } \\
\text { treatment process. Many therapists hesitate to point } \\
\text { out their pregnancy being it easy to underestimate the } \\
\text { importance of pregnancy for the patients. Gender } \\
\text { differences in the reactions of patients are not fully } \\
\text { understood, and it can be difficult to cope and } \\
\text { facilitate the expression of them with male patients. }\end{array}$ \\
\hline Stuart, J.J. & 1997 & $\begin{array}{l}\text { Describe the repercussions } \\
\text { of the gradual and physical } \\
\text { of the therapists pregnancy. }\end{array}$ & $\begin{array}{l}\text { Experience } \\
\text { report }\end{array}$ & $\begin{array}{l}\text { Three therapist pregnancy characteristics are consid- } \\
\text { ered: (a) most often gradually becomes known; (b) the } \\
\text { pregnancy is communicated to the patient by through } \\
\text { words and also silently, (c) the task of } \\
\text { deciding when and how to discuss her pregnancy with } \\
\text { patients may be complicated by her desire for patients } \\
\text { to recognize this. }\end{array}$ \\
\hline Napoli, M. & 1999 & $\begin{array}{l}\text { Identify the changes in the } \\
\text { patterns of missed sessions } \\
\text { and in payment of six } \\
\text { female patients before and } \\
\text { after the therapist } \\
\text { becoming pregnant }\end{array}$ & $\begin{array}{l}\text { Quantitative, } \\
\text { descriptive } \\
\text { and } \\
\text { longitudinal }\end{array}$ & $\begin{array}{l}\text { The patients missed significantly more sessions during } \\
\text { the pregnancy than before. There were no significant } \\
\text { differences regarding payments. }\end{array}$ \\
\hline Tinsley, J.A. & 2000 & $\begin{array}{l}\text { Explore issues of the } \\
\text { Psychiatrists pregnancy } \\
\text { practice at the beginning of } \\
\text { the Professional career. }\end{array}$ & $\begin{array}{l}\text { Literature } \\
\text { review }\end{array}$ & $\begin{array}{l}\text { Motherhood experience is important for professional } \\
\text { growth. Relations with patients can be facilitated if } \\
\text { potential problems are recognized. It is a challenge, in } \\
\text { organizations, to obtain investment policies for family } \\
\text { oriented clinics. }\end{array}$ \\
\hline $\begin{array}{l}\text { Tinsley, J.A., \& } \\
\text { Mellman, L.A. }\end{array}$ & 2003 & $\begin{array}{l}\text { Illustrate and discuss the } \\
\text { patient's reactions when } \\
\text { facing the pregnant } \\
\text { therapist. }\end{array}$ & Case report & $\begin{array}{l}\text { Common themes emerge when the therapist is } \\
\text { pregnant and the analysis of the countertransferential } \\
\text { feelings help in understanding them. }\end{array}$ \\
\hline $\begin{array}{l}\text { Dyson, E., \& } \\
\text { King, G. }\end{array}$ & 2008 & $\begin{array}{l}\text { Describe the implications } \\
\text { and impact of the pregnant } \\
\text { therapist in clinical practice }\end{array}$ & $\begin{array}{l}\text { Experience } \\
\text { report }\end{array}$ & $\begin{array}{l}\text { Pregnancy provides how to work dyadic issues and } \\
\text { triangulation. }\end{array}$ \\
\hline $\begin{array}{l}\text { Tonon, C.B., } \\
\text { Romani, P.F., \& } \\
\text { Grossi, R. }\end{array}$ & 2012 & $\begin{array}{l}\text { Describe the therapeutic } \\
\text { relationship during the } \\
\text { therapist's pregnancy }\end{array}$ & $\begin{array}{l}\text { Qualitative } \\
\text { observational, } \\
\text { of an } \\
\text { exploratory } \\
\text { nature }\end{array}$ & $\begin{array}{l}\text { Pregnancy presents intense reflections, modifying the } \\
\text { relationship and allowing to explore more primitive } \\
\text { conflicts by reliving them. The stage of treatment, the } \\
\text { level of trust and management of countertransference } \\
\text { influence the progress of the case. }\end{array}$ \\
\hline $\begin{array}{l}\text { Korenis, P., \& } \\
\text { Billick, S.B. }\end{array}$ & 2014 & $\begin{array}{l}\text { Discuss the effects and } \\
\text { negative results of the } \\
\text { therapist's pregnancy }\end{array}$ & Case study & $\begin{array}{l}\text { The therapist should prepare for what cannot be } \\
\text { under control. It is encouraged that the therapist plan } \\
\text { the pregnancy period well, considering the possibility } \\
\text { of having a replacement therapist if necessary. In the } \\
\text { case of a negative pregnancy outcome, the therapist } \\
\text { must ensure her own mental stability before returning } \\
\text { to her clinical duties and exploring with the patients } \\
\text { her feelings of anger and abandonment. }\end{array}$ \\
\hline
\end{tabular}

are specific to the therapist's physical changes.

They divide the reactions of the patients into quarters. Initially, the patients present answers focused on the pregnancy, the separation and the refor- mulation of the non-resolved parental con-flicts, with an intensification of the maternal transference. The second quarter is like an intermediate phase, where the therapist's sexuality becomes more evident 
due to the physical changes. At this time, more specifically, sexual worries appear and issues related to parenting and rivalry among siblings. In the final phase of the pregnancy, in parallel with noticeable physical changes, one realizes that the baby is on the way. This phase is dominated by separation and ending problems.

For Tinsley and Mellman (2003), during the evolution of the psychotherapist's pregnancy, there are nodal points in which the patient's reactions can become more evident. Those points would be: when the patient knows that the psychotherapist is pregnant, during the final consultations / sessions, when the ending plans are being organized, during maternity leave, when the separation is real and when the psychotherapist returns to work and the patient is conscious that the psychotherapist has demands outside the consulting room /clinic.

Four works addressed the reactions related to gender issues (Diamond, 1992; Domash, 1984; Korol, 1995). Diamond, 1992 reported three clinical cases (a woman and two men), attended to by her, and sought to discuss the specific transferential issues of each gender. However, Domash (1984) and Korol (1995) refer only to female patients, highlighting their peculiarities.

The three authors (Diamond, 1992; Domash, 1984; Korol, 1995) agree that the therapist's pregnancy intensifies maternal, erotic and aggressive conflicts. Domash (1984) and Korol (1995) refer that the therapist's pregnancy can be a rich opportunity, for female gender patients, to work on their pre-oedipal conflicts such as developmental difficulties, including separation problems, of ego formation through the transfe-rence it creates.

Al-mateen (1991) exemplifies these pre-oedipal issues describing the case of a 28-year old Police woman, who complained of head aches, emotional instability and fits of rage after an accident at work. She also suffered from insomnia, weight loss, diminished libido and concentration. A strong subject developed in her therapy was the patient's ambivalence between being "traditionally feminine" and "tough". Three weeks after the therapist discovers her own pregnancy, the patient reported she was pregnant and feeling ambivalent. The therapist became like a model for the patient and the pregnancies of both of them, at the same time, worked as a catalyzer to work on the existing conflicts.

Diamond (1992) seems to deepen the issue a bit more, setting that for both patients, men and women, pregnancy evoked ambivalent feelings about procreation and fertility functions, as well as in relation to the foetus and the mother-child link. In the meantime, for men the regressive identification with precocious and primitive maternal functions generated an intense oedipal rivalry, primitive sadistic impulses and childish/infantile regression. While for female patients, envy and identification with the therapist's maternal functions appeared relatively late in the treatment, after analysis and partial solving of conflicts surrounding the devaluation of the feminine reproductive functions and femininity, leading to a higher consolidation of a feminine integrated identification.

According to Napoli's (1999) and Rosenthal's (1990) experiences, the therapist's pregnancy corresponds to a particularly turbulent period of the therapy, demanding and productive for the therapist and the patient, which can cause ambivalences and instabilities in both. A challenge in the transference of that period are the feelings of lack of control about the setting that the patient presents, when seeing a "third"/"intruder" emerging invariably. Such context increases the conscience of the patient regarding her dependence on the therapist, with either fears of loosing her, and an intensifying of the existing emotional conflicts. Being this a moment of the treatment in which an increase of the acting outs of the patients, such as being late, missing sessions, delays in the payment of the sessions and abandoning the treatment (Napoli, 1999).

The therapist's pregnancy catalyzes the emergence of issues both in the therapist as well as in the patients. In this way, many difficulties are presented to the psychotherapist during this period and, in this sense, the psychotherapist's pregnancy, besides causing transferential reactions in her patients, triggers own experiences and triggers own and personal experiences in it. To consider and understand the countertransferential responses assist in the analysis of the transferential needs of the patient and the progress of the treatment (Cole, 1980; Tinsley \& Mellman, 2003).

One of the difficulties is the feeling of guilt regarding the patients due to the fantasies related to interrupting the clinics and the desire of dedicating all her time to maternity and the baby that will arrive (Bienen, 1990; Diamond, 1992; Domash, 1984; Tinsley \& Mellman, 2003). Another difficulty can be a sensation of being self-absorbed, sleepy, distracted or less available to listen to the patient (Bienen, 1990; Tinsley \& Mellman, 2003) finding difficulties to facilitate the expression of feelings of aggression or envy. In some situations, these dynamics contribute to a distancing of the patient's emotions and a collusion with the patient denial and avoidance of these effects (Domash, 1984). Those difficulties have an influence on the formation of the professional identity of the therapist (Stuart, 1997; Tinsley, 2000).

Besides the effects the pregnancy causes the patient and the therapist, some works will also argue the repercussion on the therapeutic relation (Korenis \& Billick, 2014; Korol, 1995; Stockman \& Green-Emrich, 1994). In a study performed by Tonon et al. (2012), which had as his aim to describe the therapeutic relation during the psychotherapists gestation period, 
changes in the psychotherapeutic process were identified, interfering in the therapeutic relation and acting consciously and unconsciously on psychic factors of both, favoring the childhood experience of the patients, providing opportunities for the emergence of feelings and conflicts in the setting.

Few studies deepen about the subject of the return after maternity leave. Chiaramonte (1986) suggests there is an intense involvement of the patients with the current moment of the psychotherapists' life. Therefore, the patient might feel less important or even excluded from the psychotherapist's life during the time of the maternity leave. A previous and individualized planning would be necessary, on how to organize this period. The return from the mater-nity leave is very seldom discussed in the literature, but of a high clinical importance, needing more studies with this focus (Chiaramonte, 1986; Korol, 1995; Stockman \& Green-Emrich, 1994).

In synthesis, the works point in the direction that the impact of pregnancy on the process is considerable, in view that it involves a wide range of factors (of the patients as well as of the therapist). It seems that the pregnancy experiences reconnect adults with their childhood experiences, catalyzing fantasies, desires and more precocious fears through transference. Many parallel processes seem to take place and, the therapist must remain conscious of her own perceptions and reactions, for her to be able to answer her patients precisely and facilitate the treatment.

Regarding the studies developed with children, a synthesis of them is presented in Table 2. The articles were in their entirety from North America, reported clinical cases and were based on psychoanalytic theory. Similar to the studies deve-loped with adults, all works made it clear that they were clinical cases, reported from the authors' experience. It is important to highlight that no study using quantitative methods was found. The articles found were 21 years old, or more. Their results indicated that the therapist's pregnancy presents important repercussions in child psychoanalytic psychotherapy, all of them emphasizing the impact of the gestation on the patient and how the psychotherapists perceived this impact. It was also described that the pregnancy can be an opportunity for the patient to work on his most primitive fantasies, being this one more way of accessing the unconscious and its desires. One article emphasized the countertransference in child psychotherapy. However, none addressed the psychotherapeutic process and/or considered the perspective, neither of the child nor of his or her family.

Paluszny and Poznanski (1971) discussed the reactions of their patients at the time of their pregnancies. Each of the authors was attending their psychiatry residency course, in different places, when they became pregnant. During that time, they attended to adult and child patients in hospital and outpatient environments. A few years later, when they compared their experiences, they noticed some similarities related to the reactions of patients. In total, eight cases were discussed: four adults and four children. The adults were aged between 20 and 38 years old and sought treatment for different diagnosis (important performances, psychotic, depressive and anxiety symptoms). The children were all boys with ages between seven and a half and eleven years old, and sought psycho-therapy because of externalizing and internalizing symptoms. The cases were divided into three categories, according to the reaction when facing pregnancy. The first group included the patients who tried to solve childhood conflicts in the relation with the pregnant therapist. The second group presented a variety of defensive reactions, in response to pregnancy. The third group, unlike the previous group, was able to integrate in the therapy the new material that was stimulated by the pregnancy.

Ashway (1984) explored the pregnancy and its implications on the treatment and clinical work with children. She presented a vignette of a clinical case of a 10-year old girl at the time of her pregnancy. The girl was in individual therapy once a week, during a year, before the pregnancy. She was a child in latency that was taken to therapy due to her parents divorce. Her father was worried about her high level of anxiety, emotional immatu-

Table 2. Description of the articles identified

\begin{tabular}{|c|c|c|c|c|}
\hline Author & Year & Objective & Study Design & Main Results \\
\hline $\begin{array}{l}\text { Paluszny, M., \& } \\
\text { Poznansky, E. }\end{array}$ & 1971 & $\begin{array}{l}\text { Reactions of patients during pre- } \\
\text { gnancy of therapist }\end{array}$ & Case study & $\begin{array}{l}\text { Although some patients showed a temporary } \\
\text { setback in therapy, no permanent regressions } \\
\text { were seen. }\end{array}$ \\
\hline Ashway, J.A. & 1984 & $\begin{array}{l}\text { Therapist pregnancy as an oppor- } \\
\text { tunity for conflict resolution and } \\
\text { growth in the treatment of child- } \\
\text { ren }\end{array}$ & $\begin{array}{l}\text { Experience re- } \\
\text { port }\end{array}$ & $\begin{array}{l}\text { The therapist's pregnancy can provide an op- } \\
\text { portunity for conflict resolution and growth, if } \\
\text { the process is handled in a therapeutically } \\
\text { sound and sensitive way. }\end{array}$ \\
\hline Callanan, D.L. & 1985 & $\begin{array}{l}\text { Children's reactions to their the- } \\
\text { rapist's pregnancy }\end{array}$ & $\begin{array}{l}\text { Experience re- } \\
\text { port }\end{array}$ & $\begin{array}{l}\text { Telling the children of the pregnancy seemed } \\
\text { to be more beneficial for the process than is } \\
\text { conventionally taught. }\end{array}$ \\
\hline $\begin{array}{l}\text { Simonis-Gayed, } \\
\text { D., \& Levin, L. }\end{array}$ & 1994 & $\begin{array}{l}\text { Children's transference and } \\
\text { countertransference }\end{array}$ & Case study & $\begin{array}{l}\text { Children have intense transference of early } \\
\text { feelings of dependency and separation }\end{array}$ \\
\hline
\end{tabular}


rity and extreme insecurity. The father reported that the girl, many times, felt jealous of her sister. The case illustrated how a child can use the experience of the therapist becoming pregnant, throughout the psychotherapeutic process, to work on the feelings and conflicts not solved before.

The third work identified is authored by Callanan (1985), who reported the psychotherapeutic treatment of 14 children aged 4 to 16 during her pregnancy. Out of these 14 children, half of them were girls and the other half were boys. She reported her approach of waiting for the pregnancy to be discovered by the patients. The reactions of the children faced with the pregnancy and the means to discover it were discussed in the article. The authoress raised the hypothesis that some children need that the therapist inform, well in advance of her pregnancy, to allow a substantial discussion of the separation problems.

Also, in the same study, with two adolescents, a 14 year-old boy and a 15 year-old girl, with histories of loss and sexual abuse respectively, both with difficulties in school performance, the therapist decided to let them know about the pregnancy before the changes in her appearance became perceptible, since she thought that this would strengthen the engagement of the patients in the treatment. Callanan (1985) reported that three patients (two girls and a boy) would question directly about her pregnancy, all of them with important experiences of losses and difficulties in the separation. Two pre-adolescents with conflicts of a depressive order related to the parent figures, asked if the therapist had any children. A 5 year-old child, very resistant and with a hyperactive and destructive behaviour, found out through her mother that her therapist was 8 months pregnant. The other six patients (two girls - 4 an 6 years old and four boys aged 6, 7, 12 and 13) that were undergoing treatment for externalizing beha-viours, remained oblivious to the pregnancy until the third quarter.

The most recent article was authored by SimonisGayed and Levin (1994), who discussed how the therapist's pregnancy has an influence on the transference in child treatment. They presented clinical cases in treatment during the pregnancy of the first authoress. Six cases of patients were presented with ages between three and a half years old and sixteen, divided as well into boys and girls. The first three cases reported (two boys, one 9 years old and the other one 15 and a 15 year-old girl) were being treated due to presenting quite aggressive and destructive behaviour. The three last cases (a three and a half year-old boy and two girls, 9 and 16 years old respectively) were children who had experienced abandonment, adoption and sexual abuse. In con-clusion, the authors made some recommendations: 1) announcing the pregnancy until the beginning of the third quarter, 2) the therapist must be aware of her own physical changes and limitations, 3) inform co-workers about how to handle issues related to pregnancy, 4) be prepared to deal with specific issues of their patients about pregnancy, 5) if the patient has siblings, be aware of the child's position in the birth order, 6) use toys, since they facilitate the expression of affections, 7) define the date of the maternity leave and 8) the therapist must pay attention to her own emotional changes starting from pregnancy.

A lack of studies was perceived focused on child psychotherapy when the psychotherapist is pregnant. The reviewed works, as they are experience reports, are rich in clinical examples that present, in a clear way, the patients' transferential expressions and manifestations. Two studies reported that the news that the psychotherapist is pregnant mobilizes in the children their feelings, awakening a sense of competition, rivalry, Oedipal conflicts, problems experienced in the mother-infant relationship, feelings of loss and envy, making them feel that the psychotherapist might abandon them (Ashway, 1984; Callanan, 1985). In the playing material of the majority of the reported clinical cases, feelings appear about attacks to the mother's inside, destruction of babies, jealousy, persecutory fantasies, difficulties to enter the consulting room, resistance to come to the session and questionings about the therapist's ability to be a mother (Ashway, 1984; Callanan, 1985).

In Callanan's practice (1985), the children who perceived or received the news earlier had more time to discuss their fantasies with the psychotherapist, which helped in the process. On the other hand, Simonis-Gayed and Levin (1994) extended that period, considering it important to notify their patients until the beginning of the third quarter. Authors who wrote about the subject (Rosito, Silva \& Cervo, 1994; Bornholdt, 2008) agreed that not always is there a direct mention of pregnancy in the associative material of the patients. Sometimes, there is an allusion to it, revealing the unconscious percep-tion that may leave the psychotherapist in doubt about which is the time to interpret the material.

The works reviewed inform that the pregnancy accentuates and influences the transference with the therapist (Ashway, 1984; Paluszny \& Posnansky, 1971; Simonis-Gayed \& Levin, 1994). During the pregnancy, the children develop an intense transference of early feelings of dependence and separation, probably due to their more recent experience of childhood and of their dependence from adults (Ashway, 1984; Simonis-Gayed, Levin, 1994). This makes of this period a good opportunity to work on development difficulties, pre-oedipal issues, problems about separation and individuation, and the formation of the child's ego (Ashway, 1984; Callanan, 1985; Paluszny \& Poznansky, 1971).

The experiences reported by Simonis-Gayed and Levin (1994) emphasize that the pregnancy made the children identify with the baby about to be born and presented themselves with a brother transference. 
Those patients presented issues related to unsatisfied necessities throughout their childhood, feelings of rivalry among siblings and fear of abandonment. The authors point out the importance of working, through the transference, the mother-son relationship at this stage.

Regarding the characteristics of each gender, Callanan (1985) reported that her boy patients had difficulties in dealing with issues related to sexuality. While the work performed by Ashway (1984) found particularly that with girls, during puberty, the fact of the psychotherapist being pregnant provides a great opportunity to talk about aspects related to sex, sexuality, reproduction, gender differences and sexual identity issues. It becomes possible to open a space in the session to explore questions and issues the patient has about the subject (what should be done in order to avoid children, how do you become pregnant and abortion), which can be very beneficial for the development of a pre-adolescent under treatment (Ashway, 1984).

Paluszny and Poznanski (1971) reported four cases of children in latency. The reactions evoked by the psychotherapist being pregnant were expressions of anger, feelings of being unloved, fear of being abandoned, regressive behavior, denial as a defense reaction, curiosity about the birth and identification with the baby.

In this way, the reactions described are so varied as patients are varied and, as well as, their psychotherapists. The way to approach pregnancy is variable depending on each professional, of her disposition to expose herself or not. It seems that a definite pattern does not exist that can guarantee that, in this way, patients will remain in therapy or not (Espinosa, 2011).

According to the reviewed studies, both adults and chidren, the majority of authors emphasizes the positive impact of the psychotherapist being pregnant in psychotherapy, a phenomenon seen as a facilitator of transference, a growth promotion tool and even being a facilitating key in a fragile alliance (Al-Mateen, 1991; Ashway, 1984; Bienen, 1990; Callanan, 1985; Diamond, 1992; Domash, 1984; Dyson \& King, 2008; Genende, 1988; Korol, 1995; Rosenthal, 1990; Simonis-Gayed \& Levin, 1994; Stockman \& Green-Emrich, 1994; Tonon et al. 2012; Underwood \& Underwood, 1976). However, some authors highlight the importance of the way in which the therapist will understand and conduct the process for a certain outcome (positive or negative) of the treatment (Bienen, 1990; Cole, 1980; Chiaramonte, 1986; Korenis \& Billick, 2014; Korol, 1995; Napoli, 1999; Stockman \& Green-Emrich, 1994; Tinsley \& Mellman, 2003).

However, in the literature in general, there are authors that defend that same position of facilitation of the treatment (Bornholdt, 2008; Motta, 2009; Pandolfo 2002), and others who point out that they perceive, as a common outcome, the patients ending their treatment prematurely (Fenster et al., 1986). In other words, the psycho-therapist's pregnancy seems to have a great potential both as a facilitator, as well as a breaker of the treatment, depending on the patients' capacity, and that of the psychotherapist, in analyzing those contents. The premature end of the treatment potential seems to be higher in patients whose treatment was already tenuous (Bassen, 1988).

All the articles found describe, in some way, the reactions of the patients when faced with the therapist's pregnancy. The works carried out with adults describe and discuss in a deeper way the reactions and their meanings in the process (Al-Mateen, 1991; Cole, 1980; Domash, 1984; Dyson \& King, 2008; Genende, 1988; Tinsley \& Mellmann, 2003; Tonon et al., 2012; Underwood \& Underwood, 1976), even reactions according with the period of the gestation (Chiaramonte, 1986; Genende, 1988; Tinsley \& Mellmann, 2003; Underwood \& Underwood, 1976). Where children are involved, the studies bring rich clinical examples, although those articles are scarcer, with less pathologies being discussed. Even though, the studies show that children's reactions are more physical, while with adults they are more subtle.

Regarding gender issues, in both age groups, we found works about the subject, works with adults (AlMateen, 1991; Diamond, 1992; Domash, 1984; Korol, 1995) show that with women the conflicts intensified issues such as pre-Oedipal, about femininity and sexuality. And with men, there was a regressive identification with precocious and primitive maternal functions, that generated a childish regression. With the children, it was a bit different. The boys had difficulty in working issues related to sexuality and the girls discussed aspects related to sex, sexuality, reproduction, gender differences and sexual identity themes (Ashway, 1984; Callanan, 1985). One hypothesis is that with children the current conflict is more worked upon, or that the experience is much more recent, which favors the therapeutic work with them much more than with adults.

The articles identified deal with the various difficulties faced by the psychotherapist during this period (Bienen, 1990; Diamond, 1992; Domash, 1984; Simonis-Gayed e Levin, 1994; Tinsley \& Mellman, 2003). However, a higher emphasis about this subject is perceived in the articles about adult patients (Bienen, 1990; Diamond, 1992; Domash, 1984; Tinsley \& Mellman, 2003), being it necessary yet to be more developed and discussed in the ambience of children. A hypothesis to explain this result is that in the literature about psychotherapy and research in psychotherapy in general, there are more studies available with adult patients, with this tendency repeating itself regarding the subject of the therapist's pregnancy.

Some difficulties can be discussed as well, in order to explain the smaller number of studies. One of them 
is the feeling of guilt towards the patients due to fantasies related to interrupting the attendances and to the desire to dedicate herself full-time to maternity and to the baby on the way (Bienen, 1990; Diamond, 1992; Domash, 1984; Simonis-Gayed \& Levin, 1994; Stockman \& Grenn-Emrich, 1994; Tinsley \& Mellman, 2003). Another difficulty can be a sensation of being self-absorbed, sleepy, distracted or with difficulty in listening to the patient, influencing the treatment and how the patient's material is worked (Bassen, 1988; Bienen, 1990; Domash, 1984; Fenster et al., 1986; Tinsley \& Mellman, 2003). There might be less permeability to understand some unconscious communication (Fallon \& Brabender, 2003; Luz et al., 2006), thus making it very important to study this phenomenon in depth.

In this revision, strong countertransferential feelings were reported in relation to the patients (Bienen, 1990; Callanan, 1985; Chiaramonte, 1986; Cole, 1980; Diamond, 1992; Genende, 1988; Korol, 1995; Rosenthal, 1990; Tinsley \& Mellman, 2003; Tonon et al., 2012). However, the studies with adults went deeper into the issue, discussing in an open was the difficulties of the therapists to deal with their countertransferential feelings (Bienen, 1990; Korol, 1995; Rosenthal, 1990; Tinsley \& Mellman, 2003) and raising the issue of the professional identity transformation of the therapist (Bienen, 1990; Korol, 1995; Stuart, 1997; Rosenthal, 1990; Tinsley, 2000). Regarding children, that subject is little discussed, being only pointed out that the therapists perform a protective role (Callanan, 1985).This corroborates what other authors place, in the sense that this professional may encounter difficulties in this moment of the process on the grounds that children need psychotherapists who are constant and consistent, since, in some situations, the inconsi-stencies of the adults around them was precisely what contributed to their problems. For that reason, it might be easier to ignore the physical changes of the psychotherapist by the pair so that the therapeutic process can remain unchanged (Byrnes, 2000; Luz et al., 2006).

Still in relation to countertransference, Ashway (1984) perceived, based upon her experience, that the child psychotherapist must be careful not to be too quick in tranquilizing her patients regarding her return to work, even though it may already be planned, since the impact of separation should not be minimized. Many times, perceiving children as more vulnerable than adults, the psychotherapist may tend to want to make everything all right, even to diminish her guilt to leave these so dependent and helpless little people. The discussion of the children's fantasies, about the period of separation, about how they feel, is absolutely necessary.

It is noticed that there are many gaps to be filled in and discussed. There is a lack of research about this topic, a need for updating the studies, predominance of exploratory qualitative approaches, being impor- tant to diversify the approaches and designs. The collections are retrospective to the time when the psychotherapist was pregnant, this data could be influenced by lapses and memory distortions. Maybe those gaps are related to the difficulty of planning a research of this nature, related to the occurrence of a pregnancy. Besides those aspects, the therapist might be so absorbed by her new role and with the baby about to be born that she has no mental space to study the theme.

Some authors (Al-Mateen, 1991; Ashway, 1984; Chiaramonte, 1986; Korenis \& Billick, 2014; Paluszny \& Poznanski, 1971; Stockman \& Green-Emirich, 1994; Stuart, 1997; Tonon et al., 2014) highlight that few studies address the subject of the pregnant psychotherapist. However, these authors do not analyze the reasons of this scarcity. One of the reasons, pointed out by Motta (2009), would be a tendency, of the pregnant psychotherapists, to deny the repercussions of the pregnancy, in themselves and in their patients, to not have to deal with the interference of that phenomena in the analytic setting.

The studies identified approached relevant issues and brought rich contributions about the subject. The discussions about the reactions of patients and the way this appears in the transference and countertransference, are what mainly stands out. It seems that with children this process occurs still more intensely.

Similitudes between the studies with children and with adult patients were identified. In both cases, the fact of the psychotherapist being pregnant mobilizes varied and intense reactions, becoming markedly present in the setting. In both cases, also, there are studies regarding transference and countertransference. These suggest that the therapist's pregnancy influences the psychotherapeutic treatment independently from the developmental phase of the individual.

The professional limit between psychotherapist and patient is a subject approached in researches with adult patients. On the other hand, the works performed with children, even for their shortage, they little approach that vertex, only discussing technical issues that the psychotherapist must follow. Also, it is not known if children, as well as adults, more often give their therapists presents or ask more about her personal life.

There is a consensus among the identified studies that pregnancy has an impact on the transference and countertransference, on the fantasies and anxieties of the adult and child, and on the attitudes and disposition of the therapist. Hypothesis one was supported in this study. In this sense, the repercussion can be positive or negative on the psychotherapeutic treatment. It also seems that more research is necessary to answer hypothesis two. It might be positive in the measure the phenomenon allows to catalyze and work on important aspects of the 
child's dynamics. When it is a negative repercussion it can lead, for example, to the interruption of the treatment, probably other questions related to resistance and the defences of the patient and/or the family, were already present or were part of the dynamics of the case.

Anyway, each case must be attended to and considered in their own singularity and specificity. And each pair therapist-patient establishes a singular relation that belongs to that dyad. The same pregnant therapist with different child patients might present a different experience, in the same way that different children with the same pregnant therapist will present a special experience of that process.

\section{Final considerations}

Researchers and clinicians seem to agree that the psychotherapist's pregnancy is an unique period within the process, for it being part of the psychotherapist's life that cannot be hidden from the patients. In spite of this certainty, the studies available are scarce. Within this context, in spite of it being a recurrent phenomenon, it is a theme neglected in adult and, especially, children's psychoanalytic psychotherapy research.

The literature reviewed makes it clear that there are repercussion in the treatment that will facilitate and/or hinder its progress, depending on the therapist, the patient and what both build together. It becomes important to understand that process during the psychotherapist's pregnancy. The know-ledge of changes and repercussions of pregnancy on the therapeutic process are a contribution to the field of process research and for the care of the population. A future direction for research could be to explore the perception of the patient, the therapist, the family and of the therapeutic process, as a whole, in this context.

It is important to comment that the dynamic processes that turns up in the therapeutic relations with the pregnant psychotherapist, through the transference and the countertransference, are not different to the conflicts in the psychotherapy with a nonpregnant psychotherapist. Both provide a repetition of previous experiences updated in the therapeutic relationship. Therefore the experience of pregnancy during the psychotherapeutic process seems to work as a powerful catalyst, although casual, for primitive fantasies and remarkable experiences in the patient's life course.

\section{Acknowledgements}

Preparation of this article was partially supported by a grant from the Higher Level Personnel Training Coordination (CAPES) awarded to Fernanda Munhoz Driemeier Schmidt and a Brazilian National Council for Scientific and Technological Development $(\mathrm{CNPq})$ grant awarded to Vera Regina
Röhnelt Ramires.

\section{References}

Al-Mateen, C.S. (1991). Simultaneous pregnancy in the therapist and the patient. American Journal of Psychotherapy, 45 (3), 432-444.

Araújo, M. (2005). Gênero e Psicoterapia. In: Eizerik, C.L., Aguiar, R.W., \& Schestatsky, S.S. (2005). Psicoterapia de Orientação Analítica: Fundamentos Teóricos e Clínicos (2nd ed.), Porto Alegre: Artmed.

Ashway, J. A. (1984). A therapist's pregnancy: An opportunity for conflict resolution and growth in the treatment of children. Clinical Social Work Journal, 12(1), 3-17.

Bassen, C.R. (1988). The impact of the analyst's pregnancy on the course of the analysis. Psychoanalytic Inquiry, 8 (2), 280-298.

Beutler, L., E., Malik, M., Ali Mohamed, S., Harwood, T.M., Talebi, H., Noble, S., \& Wong, E. (2004). Therapist variables. In: Lambert, M. (2004). Bergin and Garfield's Handbook of Psychotherapy and behavior change, 227-306. New York: John Wiley \& Sons.

Bienen, M. (1990). The pregnant therapist: Countertransference dilemmas and willingness to explore transference material. Psychotherapy: Theory, Research, Practice, Training, 27(4), 607.

Bornholdt, E. (2008). O impacto da gravidez da terapeuta no tratamento psicoterápico: quando explicitar a percepção in(consciente) da gravidez. Psicoterapia Psicanalítica, 10, 60-70.

Byrnes, M.J. (2000). The impact of therapist pregnancy on the process of child psychotherapy (Doctoral dissertation)

Callanan, D.L. (1985). Children's Reactions to Their Therapist's Pregnancy. Child Psychiatry and Human Development, 16(2), 113-119.

http://link.springer.com/article/10.1007\%2FBF0070594 5\#page-1

Caron, N.A., Bornhold, I., Mondzrak, V.S., Heck, M.M., Wolf, M.P. \& Fortes, S.D. (2000). Perfil da prática psicanalítica de crianças e adolescentes no Brasil. Revista de Psicanálise, 7 (2), 317- 347.

Ceitlin, L.H.F., Wiethaeuper, D. \& Goldfred, P.R.M. (2003). Pesquisa de resultados em psicoterapia de orientação analítica: Efeito variáveis do terapeuta. $R e$ vista Brasileira de Psicoterapia, 5, 81-95.

Chiaramonte, J.A. (1986). Therapist pregnancy and maternity leave: maintaining and furthering therapeutic gains in the interim. Clinical Social Work Journal, 14 (4), 335-347.

Cole, D. (1980). Therapeutic Issues Arising From the Pregnancy of the Therapist. Psychotherapy: Theory, research and Practice, 17 (2), 210-213.

Diamond, D. (1992). Gender-Specific Transference Reactions of Male and Female Patients to the Therapist's Pregnancy. Psychoanalytic Psychology, 9 (3), 319-345.

Domash, L. (1984). The preoedipal patient and pregnancy of the therapist. Journal of Contemporary Psychotherapy, 14 (2), 109-119.

Dyson, E. \& King, G. (2008). The pregnant therapist. Psychodynamic Practice, 14 (1), 27-42. doi: $10.1080 / 14753630701768958$.

Eizirik, C.L., \& Hauck, S. (2007). Psicanálise e psicoterapia de orientação analítica. In: A.V. Cordioli (Org). Psicoterapias: Abordagens atuais (pp. 151-166). 3a ed. Porto Alegre: Artmed.

Espinosa, Y.M. (2011, may). El embarazo de la analista: creación y destrucción de un espacio para soñar. Trabalho apresentado na Sociedade Psicanalítica de Porto Alegre, Porto Alegre. 
Etchegoyen, A. (1993). The analyst's pregnancy and its consequences on her work. International Journal of PsychoAnalysis, 74, 141-149.

Fallon, A. E., \& Brabender, V. (2003). Awaiting the therapist's Baby: A Guide for Expectant Parent-practitioners. Routledge.

Fenster, S., Phillips, S., \& Rapoport, E. (1986). The therapsit's pregnancy: instrusion in the analytc space. Hilsdale, NJ: The Analytic Press, 142pp.

FILHO, I.A.P. (2010). A subjetividade do analista nos labirintos da cura. Revista da Sociedade Brasileira de Psicanálise de Porto Alegre, 12 (2), 425-435.

Fuller, R.L. (1987). The impact of the therapist's pregnancy on the dynamics of the therapeutic process. Journal of the American of Psychoanalysis, 15 (1), 9-28.

Genende, J. (1988). A Therapist's Pregnancy: An opportunity for conflict resolution and growth in the treatment of homosexual men. Clinical Social Work Journal, 16(1), 66-77.

Hacham-Lynch, R. (2014). The pregnant therapist: an exploration of countertrasnference issues and their impacto on the tehrapeutic relationship. Retirado de: http://hdl.handle.net/10788/1880

Kernberg, O. (2006). A psicanálise, a psicoterapia psicanalítica e a psicoterapia de apoio: controvérsias contemporâneas. In: Agressividade, narcisismo e autodestrutividade na relação psicoterapêutica (pp.117-144). Lisboa: Climepsi.

Korenis, P. \& Billick, S.B. (2014). The Pregnant Therapist: The Effect of a Negative Pregnancy Outcome on a Psychotherapy Patient, Psychiatry Q, 85, 377-382. doi: 10.1007/s11126-014-9298-2.

Korol, R. (1995). The impact of therapist pregnancy on the process. Clinical Social Work Journal, 23 (2), 159-171.

Lhullier, L.A. \& Roslindo, J.J. (2013). As Psicólogas Brasileiras: levantando a ponta do véu. In: Lhullier, L.A. (2013). Quem é a Psicóloga brasileira? Mulher, Psicologia e Trabalho. Conselho Federal de Psicologia, Brasília: CFP.

Luz, A.B., Keidann, C.E., \& Dal Zot, J.S. (2006). Contratransferência e os Fatores da Vida Pessoal do Psicoterapeuta e/ou psicanalista.In: Zaslavsky, J., Santos, M.J.P. (2006). Contratransferência: teoria e prática clínica. Porto Alegre: Artmed.

Motta, I.F. (2009). Quando a psicanalista está grávida: facilitação de pesquisas sobre o interior materno e feminino. Jornal de Psicanálise, 42 (76), 91-105.

Napoli, M. (1999). Issues for Pregnant Therapists: Misssed appointments and fee payments. British Journal Of Psychotherapy, 15 (3), 355-357.

Paluszny, M. \& Posnanski, E. (1971). Reactions of patients during pregnancy of the psychotehrapist. Child Psychiat- ry and Human Development, 1(4), 226-275.

Pandolfo, A.C. (2002). A gravidez da analista e suas repercussões na relação terapêutica. Psicoterapia Psicana-lítica: Revista do Instituto de Ensino e Pesquisa em Psicoterapia Psicanalítica. 4(4), 91-107.

Rosenthal, E.S. (1990). The Therapist's Pregnancy: Impact on the treatment process. Clinical Social Work Journal, 18 (3), 213-226.

Rosito, C., Silva, E., Cervo, L. (1994). A percepção inconsciente da gravidez da terapeuta: algumas consideraçóes sobre a interpretação no processo de avaliação e contrato terapêutico. Revista CEAPLA, 4(4), 65-71.

Simonis-Gayed, D. \& Levin, L. (1994). The therapist's pregnancy: children's transference and countertransference reactions. Psychotherapy, 31 (1), 196-200.

Stockman, A.F., \& Green-Emirich, A. (1994). Impact of Therapist Pregnancy on the Process of Counseling and Psychotherapy. Psychotherapy, 31 (3), 456-462.

Stuart, J. J. (1997). Pregnancy in the therapist: Consequences of a Gradually Discernible Physical Change. Psychoanalytic Psychology, 14 (3), 347-364.

Tinsley, J.A. (2000). Pregnancy of the Earley-Career psychiatrist. Psychiatric Services, 51(1), 105-110.

Tinsley, J.A. \& Mellman, L.A. (2003). Patient Reactions to a Psychiatrist's pregnancy, American Journal Psychiatry, 160 (1), 27-31.

Tonon, C.B., Romani, P.F. \& Grossi, R. (2012). A gravidez da terapeuta e seus reflexos no processo psicoterápico. Psicologia: Teoria e Pesquisa, 28 (1), 87-92.

Underwood, M.M. \& Underwood, E.D. (1976). Clinical observations of a pregnant therapist. Social Work, 21 (6), 512-514. doi: $10.1093 / \mathrm{sw} / 21.6 .512$.

Williams, P. (2007). O que é psicanálise? O que é um psicanalista? In: E. Person, A. Cooper \& G. Gabbard (Orgs). Compêndio de Psicanálise (pp. 199-209). Porto Alegre: Artmed.

Wolfe, E. (2013). The Therapist's Pregnancy and the ClientTherapist Relationship: an exploratory study. (Doctoral Dissertation, Smith College School for Social Work). Retrieved from doi: https://dspace.smith.edu/handle/11020/24285

Zimerman, D. E. (2007). Fundamentos psicanalíticos: teoria, técnica e clínica: uma abordagem didática. Porto Alegre: Artmed.

Submitted: July 2015

Accepted: August 2015

Published: December 2015 